\title{
Overregulation in Physical Education - Teaching Behavior Effects on Self-Regulated Motor Learning
}

\author{
Sven Lindberg (Corresponding author) \\ German Institute for International Educational Research (DIPF), Frankfurt, Germany \\ Schloßstr. 29, 60486 Frankfurt am Main, Germany \\ Tel: 49-069-25707-224 E-mail: lindberg@dipf.de
}

Marcus Hasselhorn

German Institute for International Educational Research (DIPF), Frankfurt, Germany

Schloßstr. 29, 60486 Frankfurt am Main, Germany

Tel: 49-069-25707-214 E-mail: hasselhorn@ dipf.de

Martin Lehmann

German Institute for International Educational Research (DIPF), Frankfurt, Germany

Schloßstr. 29, 60486 Frankfurt am Main, Germany

Tel: 49-069-25707-211 E-mail: lehmann@dipf.de

Accepted: March 01, 2013 Published: May 03, 2013

Doi:10.5296/ijld.v3i3.3557 URL: http://dx.doi.org/10.5296/ijld.v3i3.3557

\begin{abstract}
This study examines students' use of self-regulated motor learning strategies related to a congruent or incongruent teacher-student fit-constellation of perceived and preferred teaching behavior. In a cross-sectional study in German grammar schools, 1452 students and 18 physical education teachers participated. The results of the study indicate that students apply more self-regulated motor learning strategies in specific fit-constellation. In addition, when the teachers' self-perception of teaching behavior exceeds the respective perception and preference of the students, this overregulation impairs the satisfaction with and interest in physical education as well as self-regulated motor learning
\end{abstract}

Keywords: physical education, students, self-regulation, teaching behavior, motor learning

\section{Introduction}

This study is concerned with the impact of teaching behavior on students' attitudes towards physical education (PE) and self-regulated motor learning skills. We take into account the perspectives of students and teachers on teaching behavior to examine differences in congruent and incongruent teacher-students fit-constellations, which are defined by the degree of perceived accordance between teacher and students. 
Physical education is challenged by its lasting impact on the students' physical activity and health behavior outside of school (Hagger, Chatzisarantis, Culverhouse, \& Biddle, 2003). PE should enhance the physical habits of students and promote further health related activities (Perry et al., 1990; Weir, 2000). To achieve this objective the development of physical motor skills is a crucial educational goal in PE (O'Sullivan, 2004) and physical motor learning is considered as a core curriculum for school PE (Arnold, 1991). In this regard, a PE teacher is in charge of instructing students with the relevant motor skills they need to handle their own exercise behavior, and to consequently teach them how to acquire new sports or physical skills (Dishman, Sallis, \& Orenstein, 1985; Sallis, 1987).

Motor learning and achievement is closely connected to self-regulation (Glencross, 1994; Lavisse, Deviterne, \& Perrin, 2000). Self-regulated learning is defined as a constructive process that incorporates cognition, motivation and volition (Boekaerts, 1999a; Zimmerman \& Martinez-Pons, 1990). A self-regulated learner is concerned with active goal-setting and the pursuit of monitoring, regulating and controlling cognition, motivation and behavior to reach a particular result or improvement (Elbe, Szymanski, \& Beckmann, 2005). Students can be considered as self-regulated learners if they participate metacognitively, motivationally, and behaviorally active in learning conditions (Zimmerman, 1990). Progress in self-regulated learning depends on the willingness of students to define goals, to focus on essential steps, to be active, to deal with success and failure in an appropriate way, to realize concepts and to avoid internal and external distraction (Weinert, 1994). In addition, the combined use of goals, strategies, and metacognitive knowledge determines the students' self-regulated actions (Davidson \& Stenberg, 1985). Beneficial effects of self-regulated learning have been consistently reported both in the verbal and cognitive learning domain (Boekaerts, 1999b; Schunk \& Zimmerman, 1994; Zimmerman, 1990), and from a sport science, and exercise psychology perspective in the domain of self-regulated motor learning (SRML). SRML seems to improve students' lesson comprehension and motor performance (Schunck \& Zimmerman, 1996). Moreover, SRML supports a continuing learning and performance process and it is a precondition to persevering/enduring and intensive training (Elbe et al., 2005). In addition, SRML emphasizes the interrelation between individual and contextual characteristics and achievement and performance, and the role of cognitive, emotional and motivational efforts (e.g. Lavisse et al., 2000; Lidor, 2004; Singer, DeFrancesco, \& Randall, 1989). Finally, knowledge about strategies is indispensable for students to regulate their own learning (Zimmerman \& Martinez-Pons, 1990). In PE, the application of learning strategies has a positive effect on the accuracy of performance (Lidor, 2004).

Several studies have demonstrated the efficiency of self-regulation training and strategy teaching on individual learners' motor learning (Singer \& Cauraugh, 1985; Singer et al., 1989). The effectiveness of those trainings is based on imparting learning strategies such as labeling (Winter \& Thomas, 1981), rehearsal (Gallagher \& Thomas, 1984), organization (Gallagher \& Thomas, 1986), and imagining (Feltz \& Langer, 1983). Moreover, the teaching of self-regulated learning that comprises goal setting, self-monitoring, and self-reflection processes improves motivation and achievement (Schunk, 1996).

Boekaerts (1999b) claimed that teachers have to be aware that students need a certain degree of autonomy for developing active self-regulated learning. The behavior of the teacher seems to be a strong factor regarding the students' opportunities to develop SRML (Levy, Wubbels, \& Brekelmans, 1992). SRML can be negatively affected by an overdirective teaching behavior (DeGrave, Boshuizen, \& Schmidt, 1999). An active and explicit communication style, however, seems to increase both the students' motivation to learn and their interest (Bergen, Van Amelsfoort, \& Setz, 1994) and might additionally influence their satisfaction (Brekelmans, 
Wubbels, \& Creton, 1989). Accordingly, problem-based learning environments assumingly enhance the students' ability to acquire and apply knowledge (Choi \& Hannafin, 1995). Interesting and challenging learning tasks are more likely to be recognized and they can lead to an increased strategy use. Thus, the major task of the teacher with regard to the development and advancement of SRML is to initiate, guide and encourage the students' autonomy in learning (Vermunt, 1998). In this respect, teachers are more comparable to coaches or mentors (Van Velzen, 2003) and they are required to advise and motivate their students rather than to regulate or "drill" them (Boekaerts, 1999a).

Findings from the self-determination theory (SDT; Deci \& Ryan, 2000, Ryan \& Deci, 2000) underscore the relevance of students' perceived autonomy and the role of teaching effects. Students are more intrinsically motivated and self-confident when their teachers have a communication style that supports autonomy whereas a controlling communication style seems to be less conducive (Deci et al., 1981; Chirkov \& Ryan, 2001). SDT showed that people who were offered several choices felt less controlled and they experience a higher degree of autonomy and satisfaction (Deci \& Ryan, 2000). Moreover, positive feedback can also promote intrinsic motivation when it contains competence related information (Deci, Koestner, \& Ryan, 1999). Thus, autonomy-supportive teaching and positive feedback seem to be important for the teacher's behavior repertoire.

Research has shown that PE teachers can impact upon students' motivational experiences and behavior. Adequate teaching behavior can have a significant impact on the students' levels of intrinsic motivation (Ryan, Connell, \& Deci, 1985). Motivation in PE is a crucial influencing factor for important outcomes, such as participation in optional PE (Ntoumanis, 2005) and after-school sports (Goudas, Dermitzaki, \& Bagiatis, 2001). Finally, students' satisfaction and interest in PE seem indispensable to the development of a high and motivated engagement in sports and recreational exercise (Carlson, 1995; Graham, Holt-Hale, \& Parker, 1998). It was shown that PE promotes the students' further interest in physical activity and sport (Almond \& Harris, 1998) and that adolescents who are interested and satisfied with PE were more likely to be physically active in the future (Ferguson, Yesalis, Pomrehn, \& Kirkpatrick, 1989). However, it was also noted that over time, interest and participation in PE can decrease (Anderssen, 1993; Van Wersch, Trew \& Turner, 1992). For this reason, teachers should aim at the promotion of students' motivation, satisfaction and interest.

In the field of science education and learning environments, specific instruments for the measurement of different environments, for students, teachers and teacher-student interaction have been established (Fraser, 1998). For this study it was necessary to find an instrument that is strongly related to sports contexts. A LSS version adapted for PE contexts was developed on the basis of the multidimensional leadership model provided by Chelladurai (1978) and the Leadership Scale for Sports (LSS; Chelladurai \& Saleh, 1980). Originally, the LSS consisted of five factors: (1) training and instruction, (2) democratic behavior, (3) autocratic behavior, (4) social support, and (5) positive feedback. As the subscale of autocratic behavior was not replicated in Germany, a four-factorial version of the LSS has been established (Würth, Saborowski \& Alfermann, 1999). The LSS-PE is applicable in three versions: students' preference for specific teacher behaviors, students' perception of their teacher and teachers' perception of their own behavior. According to Chelladurai's (1978) congruence hypothesis a corresponding perception of leadership behaviour by athletes and their coaches leads to a high satisfaction and better performance (Chelladurai, 1984; Horne \& Carron, 1985; Riemer \& Chelladurai, 1995). This hypothesis is supported by our own findings within the PE context where the interaction of the different LSS-PE versions was examined (Lindberg, Hasselhorn, 
\& Lehmann, submitted). In this study the reliability and construct validity of all three versions of the LSS-PE were tested and hierarchical regression analyses demonstrated that teacher behavior influences the satisfaction of students. Moreover, perceived teacher-student congruence had a positive effect on students' satisfaction

This study examines the influence of teaching behavior on students' SRML. Because of the crucial impact SRML has on PE, it seems very important to find aspects of teaching behavior that foster and maintain the students' SRML in order to provide the opportunity for an independent and natural contact with sports and physical activities in life. As demonstrated in the paragraphs above, teachers can have a decisive influence on their students' SMRL strategy use. Moreover, our own findings indicate that the teachers' and students' perceptions of teaching behavior are important for motivation and a sportive lifestyle in general. One of our main goals was to explore the differential impact of congruent versus incongruent teacher-student fit-constellations on the students' use of SRML-strategies and to identify its differentiation to students' satisfaction and interest in PE. For this purpose we applied the three versions of the LSS-PE relating to the students' perception and their preference of specific teaching behavior and the teachers' self-perception of their own behavior.

We hypothesize in accordance to our own findings (Lindberg et al., submitted) that perceived teacher-student congruence is important for students' satisfaction and interest. According to SDT, perceived autonomy is important for students' satisfaction and self-regulated behavior (Grolnick, Ryan, and Deci, 1991). We are interested in the different constellations of congruence and incongruence between students' and teachers' perception of teaching and their impact on students' perceived autonomy. Furthermore, we are interested in the constellations' impact on students' self-regulated learning.

\section{Method}

This paper is divided into three sections that refer to the corresponding constellations of the LSS-PE versions. In the first section, we analyze the congruence/incongruence between the students' perception and preference of their PE-teachers' behavior. For these analyses the LSS-PE-Student and the LSS-PE-Preference questionnaires were filled in by all of the students. For the teachers it was voluntary to fill in the LSS-PE, so it was not possible to gain a complete dataset for all of the LSS-PE versions, the other two sections include data of only those students who could be matched with the particular self-description data of their PE teachers (assessed by the LSS-PE-Teacher). While we analyze the congruence/incongruence of students' and teachers' perceptions of the actual teaching behavior in the second section, the third section addresses the congruence/incongruence of the teachers' perceptions of their own behavior and the students' preference for a particular teaching behavior. For all sections it was consequently possible to compare three groups: (1) LSS-PE scores are congruent (2) LSS-PE scores diverge positively and (3) LSS-PE score diverge negatively. Among these groups the different occurrence of students' satisfaction, interest and self-regulated learning were analyzed.

\subsection{Participants}

This study was addressed to secondary level students in German grammar schools. In order to obtain a sufficient sample size, we recruited seven schools with 49 classes. For section 1 a complete dataset of 1452 students (625 females, 798 males and 29 unstated) was obtained. Age varied from 9 to 17 with a mean of 13.31 years $(S D=1.49)$. The sample used in sections 2 and 3 consisted of 696 students (374 females, 312 males and 10 unstated) and 18 physical education teachers ( 8 females and 10 males). In this sub-sample the age differed from 9 to 17 
with an average of 13.11 years $(S D=1.54)$ for students and from 28 to 60 with a mean of 49.87 years $(S D=14.99)$ for teachers, respectively.

\subsection{Procedure and Measures}

We used four different questionnaires: the German Leadership Scale for Sports for Physical Education (LSS-PE; Lindberg et al., submitted), the StraBL (Bund \& Wiemeyer, 2005), for the assessment of students' satisfaction, a scale of four items according to the proceeding of Riemer and Chelladurai (1995) was developed. All of the items started with the phrase "How satisfied are you with..." and continued with PE-related content (e.g. "...the structure and the arrangement of the physical education classes?"). Responses were provided on a 7-point, Likert-type scale ranging from not at all satisfied (1) to extremely satisfied (7). In order to measure the students' interest in PE and sports, a scale of 14 items based on the approaches of Köller (2004) and Pohlmann, Möller, and Streblow (2005) was designed. The items were phrased as "The statement..." and referred to interest related aspects (e.g "I think PE is very important" or "I like sports"). Answers were given on a 4-point, Likert-type scale ranging from not at all true (1) to extremely true (4).

The questionnaires were administered in close collaboration with the PE teachers. After an intensive briefing and the supply of a handout instruction, the LSS-PE-Perception, the LSS-PE-Preference and the satisfaction and interest scales were delivered to all classes by the cooperating teachers. Moreover, the participating teachers were asked to fill in the LSS-PE-Teacher questionnaire. To assure anonymity all questionnaire versions were handed out with an envelope so that the document was sealed after completion.

Teachers' behavior was assessed by the German Leadership Scale for Sports for Physical Education (LSS-PE; Lindberg et al., submitted). The instrument exists in three versions: teacher perception (LSS-PE-Teacher), students' perception (LSS-PE-Student) and students' preference (LSS-PE-Preference) of physical education behavior, respectively. The questionnaires consist of 21 items that assess four dimensions of physical education behavior: Education and Instruction (7 items), Democratic Behavior (5 items), Positive Feedback (5 items), and Social Support (4 items). The items are comparable within all three versions of the LSS, they differ mainly in their introductory structure. Accordingly, the LSS-PE-Teacher version starts with "I show this behavior...", the LSS-PE-Student version starts with "My teacher..", and the LSS-PE-Preference starts with "In physical education classes it is important for me that my teacher...".

The first dimension of Education and Instruction deals with improving the students' sportive and social performance (e.g. "...explains to each student the techniques and tactics of the sport"). The second dimension, Democratic Behavior, includes behavior that allows students to participate in decision-making processes regarding the arrangements of the lesson and other activities (e.g. "... lets the students participate in decision making"). The third dimension of Positive Feedback measures behavior related to the reinforcement of students' good performance and behavior (e.g. "...compliments a student on good performance in the presence of others"). Finally, the forth dimension, Social Support, focuses on behavior that is adopted to reach and maintain a good relationship with the students and to establish a pleasant classroom climate (e.g. "...helps students with their personal problems"). Participants can rate the items on 5-point, Likert-type scales ranging from never (1) to always (5). Here, a high score represents a strong perception of teachers' behavior, whereas a low one represents a low perception of that behavior. 
The measurement of self-regulated learning ranges from the observation of overt behavior (Corno, 2001) to analyses of interviews (Perry, 2002) and diaries (Randi \& Corno, 1997). From the perspective of quantitative research, the most common instrument for assessing self-regulated learning is the Motivated Strategies for Learning Questionnaire (MSLQ; Pintrich, Smith, Garcia, \& McKeachie, 1993). The MSLQ assesses reported cognitive and metacognitive strategy use by considering the students' motivational beliefs and their techniques for managing resources in specific situations and is considered as a reliable instrument for the assessment of self-regulated learning (Artelt et al., 2000). Based on the conception of the MSLQ, Bund and Wiemeyer (2005) developed a sport-specific instrument (StraBL - Strategien beim selbstgesteuerten Bewegungslernen; possible translation: "Strategies of Self-Regulated Motor Learning") to assess learning strategies during the self-controlled learning of motor skills. This questionnaire consists of 35 items distributed across five dimensions: (1) Cognitive strategies (7 items), (2) Metacognitive Strategies (7 items), (3) Management of Internal Resources (6 items), (4) Management of External Resources (8 items), and (5) Motor Strategies (7 items). A hypothetical learning situation is applied to support the students' imagination (e.g. "...you would like to learn snowboarding without the instruction of a teacher") before they answer the specific questions. The first dimension of Cognitive Strategies refers to the elaboration and cognitive examination of motor activities (e.g. "I try to be aware of the key points of a specific move"). The second dimension Metacognitive Strategies focuses on the aspects of planning, monitoring and regulating the activity (e.g. "Before I start to practice, I think about an effective way of structuring the session"). The third dimension, Management of Internal Resources, relates to the willingness to exert oneself, and to the dedication of concentration, attention, and to individual time management (e.g. "When I lose my focus, I try to renew my concentration"). The fourth dimension, Management of External Resources, deals with the learning arrangement, learning support by peers and the use of media (e.g. "I ask others to show and explain a move"). The fifth dimension, Motor Strategies, relates to aspects of executing motor learning units and sequences (e.g. "When I practice, I start with easy moves before I try the complex ones"). Answers to the items are effected on 5-point, Likert-type scales ranging from does not apply at all (1) to applies completely (5). Thus, a high score represents a frequent use of that strategy, whereas a low score represents little use of this strategy.

Table 1 shows the internal reliability, means, standard deviations, and scale ranges of all measures. We used Cronbach's alpha coefficient for assessing internal reliability. An alpha of .70 is regarded as a cut-off for an appropriate level of reliability (Nunnally, 1978). Robinson, Shaver, and Wrightsman (1991) considered an alpha of 0.6 as sufficient in the case of newly developed scales. All subscales of the LSS-PE and the StraBL, and the scales for satisfaction and interest reached an appropriate level. Although one subscale of the LSS-PE-Teacher had an alpha of .65 we consider the instrument as suitable for this study with regard to content. The LSS-PE-Teacher were tested in a large online-sample of German PE teachers and the subscale reached an appropriate alpha of .74 (Lindberg et al., submitted). Teacher mean scores were generally higher than those of the students. The strategy scores of the StraBL were rather high and the means for satisfaction and interest turned out to be moderate. 
Table 1

Internal consistencies and descriptive statistics for each measure

\begin{tabular}{lllll}
\hline Measure & $\alpha$ & M & SD & Scale range \\
\hline LSS-PE-Student (Instruction) & .86 & 3.46 & 0.85 & $1-5$ \\
LSS-PE-Student (Democratic) & .84 & 3.04 & 0.96 & $1-5$ \\
LSS-PE-Student (Positive Feedback) & .84 & 3.41 & 0.96 & $1-5$ \\
LSS-PE-Student (Social Support) & .87 & 2.97 & 1.04 & $1-5$ \\
LSS-PE-Preference (Instruction) & .84 & 3.68 & 0.79 & $1-5$ \\
LSS-PE-Preference (Democratic) & .83 & 3.74 & 0.85 & $1-5$ \\
LSS-PE-Preference (Positive Feedback) & .81 & 3.80 & 0.87 & $1-5$ \\
LSS-PE-Preference (Social Support) & .84 & 3.59 & 0.92 & $1-5$ \\
LSS-PE-Teacher (Instruction) & .65 & 4.22 & 0.36 & $1-5$ \\
LSS-PE-Teacher (Democratic) & .76 & 3.44 & 0.52 & $1-5$ \\
LSS-PE-Teacher (Positive Feedback) & .83 & 4.39 & 0.36 & $1-5$ \\
LSS-PE-Teacher (Social Support) & .74 & 3.87 & 0.60 & $1-5$ \\
StraBL-Cognitive Strategies & .80 & 3.41 & 0.79 & $1-5$ \\
StraBL-Metacognitive Strategies & .81 & 3.51 & 0.80 & $1-5$ \\
StraBL-Internal Resources & .71 & 3.40 & 0.75 & $1-5$ \\
StraBL-External Resources & .79 & 3.23 & 0.78 & $1-5$ \\
StraBL-Motor Strategies & .77 & 3.37 & 0.76 & $1-5$ \\
Satisfaction & .91 & 4.61 & 1.74 & $1-7$ \\
Interest & .86 & 2.93 & 0.57 & $1-4$ \\
\hline
\end{tabular}

An overview of the intercorrelations of the LSS-PE versions and the StraBL subscales and the scales for satisfaction and interest is displayed in Table 2. For the LSS-PE-Student and LSS-PE-Preference we found positive correlations with all subscales of the StraBL. On average, the correlations for the LSS-PE-Preference seem to be slightly stronger. The LSS-PE-Teacher, however, was unrelated to the StraBL subscales. Moreover, all versions of the LSS-PE but not the subscale Social Support of the LSS-PE-Teacher were correlated with the scales for satisfaction and interest. In general, students' satisfaction and interest in PE were particularly related to the students' perception of their teacher's behaviour.

Table 2

Pearson's correlations between the LSS-PE versions and StraBL, Satisfaction and Interest

\begin{tabular}{|c|c|c|c|c|c|c|c|c|c|c|c|c|}
\hline \multirow[b]{2}{*}{ Variable } & \multicolumn{10}{|c|}{ LSS-PE Version } & \multirow[b]{2}{*}{$\begin{array}{l}\text { Pref. } \\
\text { Pos. }\end{array}$} & \multirow[b]{2}{*}{$\begin{array}{l}\text { Pref. } \\
\text { Soc. }\end{array}$} \\
\hline & $\begin{array}{l}\text { Stud. } \\
\text { Inst. }\end{array}$ & $\begin{array}{l}\text { Stud. } \\
\text { Dem. }\end{array}$ & $\begin{array}{l}\text { Stud. } \\
\text { Pos. }\end{array}$ & $\begin{array}{l}\text { Stud. } \\
\text { Soc. }\end{array}$ & $\begin{array}{l}\text { Teach. } \\
\text { Inst. }\end{array}$ & $\begin{array}{l}\text { Teach. } \\
\text { Dem. }\end{array}$ & $\begin{array}{l}\text { Teach. } \\
\text { Pos. }\end{array}$ & $\begin{array}{l}\text { Teach. } \\
\text { Soc. }\end{array}$ & $\begin{array}{l}\text { Pref. } \\
\text { Inst. }\end{array}$ & $\begin{array}{l}\text { Pref. } \\
\text { Dem. }\end{array}$ & & \\
\hline $\begin{array}{l}\text { StraBL-Cognitive } \\
\text { Strategies }\end{array}$ & $.29 * *$ & $.28 * *$ & $.30 * *$ & $.26 * *$ & .03 & .00 & .03 & .03 & $.39 * *$ & $.34 * *$ & $.32 * *$ & $.32 * *$ \\
\hline $\begin{array}{l}\text { StraBL-Metacognitive } \\
\text { Strategies }\end{array}$ & $.27 * *$ & $.26^{* *}$ & $.30 * *$ & $.24 * *$ & .06 & -.01 & .03 & .06 & $.43 * *$ & $.36^{* *}$ & $.36 * *$ & $.35 * *$ \\
\hline $\begin{array}{l}\text { StraBL-Internal } \\
\text { Resources }\end{array}$ & $.24 * *$ & $.24 * *$ & $.26^{* *}$ & $.23 * *$ & .04 & -.02 & .02 & .02 & $.38 * *$ & $.32 * *$ & $.30 * *$ & $.30 * *$ \\
\hline $\begin{array}{l}\text { StraBL-External } \\
\text { Resources }\end{array}$ & $.19 * *$ & $.22 * *$ & $.23 * *$ & $.22 * *$ & .04 & -.03 & .04 & .04 & $.36 * *$ & $.31 * *$ & $.27 * *$ & $.27 * *$ \\
\hline $\begin{array}{l}\text { StraBL-Motor } \\
\text { Strategies }\end{array}$ & $.25^{* *}$ & $.24 * *$ & $.27 * *$ & $.23 * *$ & .03 & .02 & .02 & .02 & $.37 * *$ & $.33 * *$ & $.29 * *$ & $.29 * *$ \\
\hline Satisfaction & $.58 * *$ & $.56^{* *}$ & $.51 * *$ & $.56^{* *}$ & $.25^{* *}$ & $.26 * *$ & $.30 * *$ & -.07 & $.24 * *$ & $.18 * *$ & $.21 * *$ & $.22 * *$ \\
\hline Interest & $.40^{* *}$ & $.36^{* *}$ & $.37 * *$ & $.39 * *$ & $.17 * *$ & $.13 * *$ & $.17 * *$ & -.00 & $.27 * *$ & $.17 * *$ & $.24 * *$ & $.24 * *$ \\
\hline
\end{tabular}

$* * \mathrm{p}<0.01, * \mathrm{p}<0.05$ 


\section{Macrothink}

\section{Results}

The presentation of the results is divided into three sections that are in accordance with the constellations of the LSS-PE. Thus, the first section analyzes the congruence/incongruence of students' perception and preference of teaching behavior. The second section analyzes the congruence/incongruence of students' and teachers' perception of the teaching behavior. Finally, section three refers to the congruence/incongruence of the teachers' perception of their own behavior and the students' preference for specific teaching behavior.

\subsection{Students' perception and preference}

We established three groups of students with different perception-preference combinations in order to analyse the incongruent and congruent fit-constellations of the students' perceptions and preferences of teaching behaviour: (a) students perceive more specific teaching behaviour than they prefer, (b) students perceive the degree of specific teaching behaviour they prefer, and (c) students perceive less specific teaching behaviour than they prefer. To compose the groups we built three difference scores with the LSS-PE-Student as a reference: (1) LSS-PE-Student - LSS-PE-Preference, (2) LSS-PE-Student - LSS-PE-Teacher and (3) LSS-PE-Preference - LSS-PE-Teacher. After examining the frequency distribution of the difference scores we composed the three groups of congruence and incongruence. A set of multivariate analyses of variance (MANOVA) on the four dimensions of the LSS-PE were conducted to examine the students' use of SRML strategies, with StraBL, satisfaction, and interest for PE as the dependent variables among the three groups of congruence. Table 3 provides an overview of the results for all groups and variables. In order to take into account that the students' answers are not independent but nested within groups of students attending the same class, we use class identification numbers as a covariate. Moreover, we performed the analysis with students' gender and age as covariates. No significant differences in the results were found when including the covariates. 


\section{1) Macrothink}

International Journal of Learning \& Development

ISSN 2164-4063

2013, Vol. 3, No. 3

Table 3

Students' SRML, Satisfaction and Interest among congruent and incongruent

fit-constellations of students' perceived and preferred teacher behavior

Comparison of

LSS-PE- Student and LSS-PE-Preference

\begin{tabular}{|c|c|c|c|c|c|}
\hline Variable & $F(\mathrm{df} / \mathrm{N})$ & $\begin{array}{l}\text { Student > Preference } \\
\text { (a) } \\
\mathrm{M}(\mathrm{SD})\end{array}$ & $\begin{array}{l}\text { Congruent } \\
\text { (b) } \\
\mathrm{M}(\mathrm{SD})\end{array}$ & $\begin{array}{l}\text { Student }<\text { Preference } \\
(\mathrm{c}) \\
\mathrm{M}(\mathrm{SD})\end{array}$ & $\eta^{2}$ \\
\hline \multicolumn{6}{|l|}{ Education and Instruction } \\
\hline StraBL-Cognitive Strategies & $F(2.1366)=4.92 *$ & $3.29(0.82) b c^{*}$ & $3.47(0.76) \mathrm{a}^{*}$ & $3.42(0.81) \mathrm{a}^{*}$ & 0.007 \\
\hline $\begin{array}{l}\text { StraBL-Metacognitive } \\
\text { Strategies }\end{array}$ & $\begin{array}{l}F(2.1366)=11.19 \\
*\end{array}$ & $3.31(0.85) \mathrm{bc}^{*}$ & $3.56(0.73) \mathrm{a}^{*}$ & $3.57(0.82) \mathrm{a}^{*}$ & 0.016 \\
\hline StraBL-Internal Resources & $F(2.1366)=7.06^{*}$ & $3.26(0.80) b c^{*}$ & $3.43(0.70) \mathrm{a}^{*}$ & $3.45(0.77) \mathrm{a}^{*}$ & 0.010 \\
\hline StraBL-External Resources & $F(2.1366)=9.96^{*}$ & $3.06(0.87) \mathrm{bc} *$ & $3.26(0.75) \mathrm{a}^{*}$ & $3.31(0.75) \mathrm{a}^{*}$ & 0.014 \\
\hline StraBL-Motor Strategies & $F(2.1366)=5.26^{*}$ & $3.24(0.83) b c^{*}$ & $3.41(0.70) \mathrm{a}^{*}$ & $3.40(0.74) \mathrm{a}^{*}$ & 0.008 \\
\hline Satisfaction & $\begin{array}{l}F(2.1349)=69.94 \\
*\end{array}$ & $4.93(1.72) c^{*}$ & $5.08(1.50) \mathrm{c}^{*}$ & 3.94(1.74)ab* & 0.094 \\
\hline Interest & $\begin{array}{l}F(2.1349)=14.22 \\
*\end{array}$ & $2.96(0.61) \mathrm{c}^{*}$ & $3.01(0.55) \mathrm{c}^{*}$ & $2.82(0.58) \mathrm{ab}^{*}$ & 0.021 \\
\hline \multicolumn{6}{|l|}{ Democratic Behavior } \\
\hline StraBL-Cognitive Strategies & $F(2.1364)=1.97$ & $3.31(0.79)$ & $3.42(0.85)$ & $3.44(0.79)$ & 0.003 \\
\hline $\begin{array}{l}\text { StraBL-Metacognitive } \\
\text { Strategies }\end{array}$ & $F(2.1364)=4.69^{*}$ & $3.36(0.80) \mathrm{c}^{*}$ & $3.49(0.85)$ & $3.56(0.76) \mathrm{a}^{*}$ & 0.007 \\
\hline StraBL-Internal Resources & $F(2.1364)=1.71$ & $3.32(0.77)$ & $3.39(0.80)$ & $3.43(0.72)$ & 0.003 \\
\hline StraBL-External Resources & $F(2.1364)=1.55$ & $3.18(0.83)$ & $3.20(0.85)$ & $3.27(0.74)$ & 0.002 \\
\hline StraBL-Motor Strategies & $F(2.1364)=2.61$ & $3.26(0.79)$ & $3.37(0.83)$ & $3.40(0.71)$ & 0.004 \\
\hline Satisfaction & $\begin{array}{l}F(2.1347)=37.76 \\
*\end{array}$ & $4.98(1.65) \mathrm{c}^{*}$ & $5.17(1.62) \mathrm{c}^{*}$ & $4.30(1.71) \mathrm{ab}^{*}$ & 0.085 \\
\hline Interest & $\begin{array}{l}F(2.1347)=10.98 \\
*\end{array}$ & $2.96(0.59)$ & $3.05(0.56) \mathrm{c}^{*}$ & $2.88(0.57) b^{*}$ & 0.095 \\
\hline \multicolumn{6}{|l|}{ Positive Feedback } \\
\hline StraBL-Cognitive Strategies & $F(2.1359)=1.79$ & $3.34(0.77)$ & $3.45(0.81)$ & $3.41(0.79)$ & 0.003 \\
\hline $\begin{array}{l}\text { StraBL-Metacognitive } \\
\text { Strategies }\end{array}$ & $F(2.1359)=1.32$ & $3.44(0.81)$ & $3.53(0.80)$ & $3.53(0.78)$ & 0.002 \\
\hline StraBL-Internal Resources & $F(2.1359)=1.93$ & $3.34(0.74)$ & $3.45(0.77)$ & $3.39(0.74)$ & 0.003 \\
\hline StraBL-External Resources & $F(2.1359)=0.66$ & $3.20(0.81)$ & $3.27(0.80)$ & $3.23(0.75)$ & 0.001 \\
\hline StraBL-Motor Strategies & $F(2.1359)=1.72$ & $3.32(0.76)$ & $3.42(0.77)$ & $3.35(0.73)$ & 0.003 \\
\hline Satisfaction & $\begin{array}{l}F(2.1343)=43.27 \\
*\end{array}$ & $4.81(1.73) \mathrm{c}^{*}$ & $5.08(1.53) \mathrm{c}^{*}$ & $4.15(1.75) \mathrm{ab}^{*}$ & 0.061 \\
\hline Interest & $F(2.1343)=6.90^{*}$ & $2.98(0.60) \mathrm{c}^{*}$ & $2.99(0.54) \mathrm{c}^{*}$ & $2.87(0.59) \mathrm{ab}^{*}$ & 0.010 \\
\hline \multicolumn{6}{|l|}{ Social Support } \\
\hline StraBL-Cognitive Strategies & $F(2.1361)=0.90$ & $3.37(0.84)$ & $3.45(0.81)$ & $3.40(0.77)$ & 0.001 \\
\hline $\begin{array}{l}\text { StraBL-Metacognitive } \\
\text { Strategies }\end{array}$ & $F(2.1361)=3.19^{*}$ & $3.39(0.84) \mathrm{b}^{*}$ & $3.55(0.81) \mathrm{a}^{*}$ & $3.52(0.77)$ & 0.005 \\
\hline StraBL-Internal Resources & $F(2.1361)=2.18$ & $3.31(0.75)$ & $3.44(0.79)$ & $3.41(0.73)$ & 0.003 \\
\hline StraBL-External Resources & $F(2.1361)=1.71$ & $3.16(0.81)$ & $3.29(0.83)$ & $3.23(0.78)$ & 0.003 \\
\hline StraBL-Motor Strategies & $F(2.1361)=1.50$ & $3.30(0.76)$ & $3.41(0.79)$ & $3.37(0.73)$ & 0.002 \\
\hline Satisfaction & $\begin{array}{l}F(2.1346)=54.16 \\
*\end{array}$ & $4.93(1.72) \mathrm{c}^{*}$ & $5.25(1.51) \mathrm{c}^{*}$ & $4.21(1.71) \mathrm{ab}^{*}$ & 0.075 \\
\hline Interest & $\begin{array}{l}F(2.1346)=11.88 \\
*\end{array}$ & $3.00(0.63) \mathrm{c}^{*}$ & $3.03(0.54) \mathrm{c}^{*}$ & $2.86(0.57) \mathrm{ab}^{*}$ & 0.017 \\
\hline$* \mathrm{p}<0.05$ & MANOVA & rost & & & \\
\hline
\end{tabular}


The group comparison for the LSS-PE dimension Education and Instruction revealed significant differences among all StraBL subscales. Tukey HSD post-hoc analyses revealed the following group differences: Students in group (a) used less SRML strategies than students from groups (b) and (c). The SRML strategy use in groups (b) and (c), however, did not differ. Hence, SRML strategies were affected when students perceived a higher degree of education and instructional behavior of their teachers than they actually preferred. However, both the congruence of perceived and preferred instructional behavior, and the perception of less instructional behavior than was actually preferred, leads to a higher performance in SRML strategy use. For the LSS-PE dimensions Democratic Behavior and Social Support, the same effect resulted for the StraBL subscale Metacognitive Strategies while no significant group differences resulted on any of the other subscales of the StraBL. Moreover, for the LSS-PE dimension Positive Feedback no group differences were significant concerning the StraBL subscales.

The students' satisfaction and interest in PE revealed a homogenous picture. A congruent fit-constellation regarding the students' perception and their preference of specific teacher behavior seemed to be important for satisfaction and interest in PE. This was valid for all dimensions of the LSS-PE assessment. Since groups (a) and (b), however, did not differ significantly, a higher amount of perceived teaching behavior than originally preferred also has an important impact on the students' satisfaction and interest in PE.

\subsection{Students' and teachers ' perception}

The following groups were created to analyze the incongruent and congruent fit-constellations of students' perception of their teachers behavior and the teachers' perception of their own behavior respectively: (a) students perceive more specific teaching behavior than their teacher had rated themselves, (b) the students' and teachers' perceptions of specific teaching behavior are consistent, and (c) students perceive less specific teaching behavior than their teachers rate for themselves. As can be seen in Table 4 the results were consistent for all StraBL subscales and for students' satisfaction and interest in PE and over all LSS-PE dimensions: the mean scores of all scales were higher for group (a) than for group (c). A congruence between students' and teachers' perceptions had mainly the same impact on 
Table 4

Students' SRML, Satisfaction and Interest among congruent and incongruent fit-constellations of teacher behavior perceived by students and teachers' perception of their own behavior

\begin{tabular}{|c|c|c|c|c|c|}
\hline \multirow{3}{*}{ Variable } & \multirow{3}{*}{$F(\mathrm{df} / \mathrm{N})$} & \multicolumn{4}{|c|}{$\begin{array}{l}\text { Comparison of } \\
\text { LSS-PE- Student and LSS-PE-Teacher }\end{array}$} \\
\hline & & $\begin{array}{l}\text { Student > Teacher } \\
\text { (a) }\end{array}$ & $\begin{array}{l}\text { Congruent } \\
\text { (b) }\end{array}$ & Student $<$ Teacher $(\mathrm{c})$ & $\eta^{2}$ \\
\hline & & $\mathrm{M}(\mathrm{SD})$ & $\mathrm{M}(\mathrm{SD})$ & $\mathrm{M}(\mathrm{SD})$ & \\
\hline \multicolumn{6}{|l|}{ Education and Instruction } \\
\hline StraBL-Cognitive Strategies & $F(2.662)=20.68 *$ & $3.90(0.80) \mathrm{c}^{*}$ & $3.63(0.79) \mathrm{c}^{*}$ & $3.30(0.79) \mathrm{ab}^{*}$ & 0.059 \\
\hline $\begin{array}{l}\text { StraBL-Metacognitive } \\
\text { Strategies }\end{array}$ & $F(2.662)=13.36^{*}$ & $3.93(0.85) \mathrm{c}^{*}$ & $3.69(0.80) \mathrm{c}^{*}$ & $3.44(0.78) \mathrm{ab}^{*}$ & 0.039 \\
\hline StraBL-Internal Resources & $F(2.662)=14.64^{*}$ & $3.91(0.76) b c^{*}$ & $\begin{array}{l}3.53(0.82) \mathrm{ac} \\
*\end{array}$ & $3.36(0.75) \mathrm{ab}^{*}$ & 0.043 \\
\hline StraBL-External Resources & $F(2.662)=9.37 *$ & $3.64(0.93) \mathrm{bc}^{*}$ & $3.32(0.83) \mathrm{a}^{*}$ & $3.18(0.76) \mathrm{a}^{*}$ & 0.028 \\
\hline StraBL-Motor Strategies & $F(2.662)=12.21 *$ & $3.78(0.86) b^{*}$ & $\begin{array}{l}3.51(0.75) \mathrm{ac} \\
*\end{array}$ & $3.31(0.72) \mathrm{ab}^{*}$ & 0.036 \\
\hline Satisfaction & $F(2.660)=56.13^{*}$ & $5.88(1.47) \mathrm{c}^{*}$ & $5.47(1.40) \mathrm{c}^{*}$ & 4.13(1.70)ab* & 0.146 \\
\hline Interest & $F(2.660)=28.64 *$ & $3.34(0.54) b c^{*}$ & $\begin{array}{l}3.10(0.53) \mathrm{bc} \\
*\end{array}$ & $2.82(0.59) \mathrm{ab}^{*}$ & 0.080 \\
\hline \multicolumn{6}{|l|}{ Democratic Behavior } \\
\hline StraBL-Cognitive Strategies & $F(2.662)=20.68 *$ & $3.73(0.81) \mathrm{c}^{*}$ & $3.54(0.74) \mathrm{c}^{*}$ & $3.27(0.79) \mathrm{ab}^{*}$ & 0.060 \\
\hline $\begin{array}{l}\text { StraBL-Metacognitive } \\
\text { Strategies }\end{array}$ & $F(2.662)=12.96^{*}$ & $3.77(0.83) \mathrm{c}^{*}$ & $3.64(0.76) \mathrm{c}^{*}$ & $3.41(0.78) \mathrm{ab}^{*}$ & 0.037 \\
\hline StraBL-Internal Resources & $F(2.662)=12.84 *$ & $3.68(0.83) \mathrm{c}^{*}$ & $3.52(0.77) c^{*}$ & $3.32(0.73) a b^{*}$ & 0.038 \\
\hline StraBL-External Resources & $F(2.662)=12.55^{*}$ & $3.51(0.85) \mathrm{bc}^{*}$ & $3.25(0.82) b^{*}$ & $3.14(0.75) \mathrm{a}^{*}$ & 0.037 \\
\hline StraBL-Motor Strategies & $F(2.662)=10.28 *$ & $3.62(0.82) \mathrm{bc}^{*}$ & $3.40(0.69) \mathrm{a}^{*}$ & $3.30(0.72) \mathrm{a}^{*}$ & 0.030 \\
\hline Satisfaction & $F(2.661)=20.68 *$ & $5.88(1.47) c^{*}$ & $5.47(1.40) \mathrm{c}^{*}$ & $4.13(1.75) \mathrm{ab}^{*}$ & 0.146 \\
\hline Interest & $F(2.661)=20.68^{*}$ & $3.34(0.54) b c^{*}$ & $\begin{array}{l}3.10(0.53) \mathrm{ac} \\
*\end{array}$ & $2.82(0.59) b c^{*}$ & 0.080 \\
\hline \multicolumn{6}{|l|}{ Positive Feedback } \\
\hline StraBL-Cognitive Strategies & $F(2.661)=21.77 *$ & $3.83(0.88) \mathrm{c}^{*}$ & $3.75(0.80) \mathrm{c}^{*}$ & $3.31(0.77) \mathrm{ab}^{*}$ & 0.062 \\
\hline $\begin{array}{l}\text { StraBL-Metacognitive } \\
\text { Strategies }\end{array}$ & $F(2.661)=22.56^{*}$ & $3.86(0.90) \mathrm{c}^{*}$ & $3.89(0.78) \mathrm{c}^{*}$ & $3.42(0.77) \mathrm{ab}^{*}$ & 0.064 \\
\hline StraBL-Internal Resources & $F(2.661)=18.23 *$ & $3.84(0.93) \mathrm{c}^{*}$ & $3.71(0.77) \mathrm{c} *$ & $3.34(0.74) \mathrm{ab}^{*}$ & 0.053 \\
\hline StraBL-External Resources & $F(2.661)=13.68^{*}$ & $3.55(1.06) \mathrm{c}^{*}$ & $\begin{array}{l}3.51(0.85) \\
c^{*}\end{array}$ & $3.16(0.74) a b^{*}$ & 0.040 \\
\hline StraBL-Motor Strategies & $F(2.661)=14.89 *$ & $3.65(0.97) \mathrm{c}^{*}$ & $\begin{array}{l}3.66(0.73) \\
c^{*}\end{array}$ & $3.30(0.71) \mathrm{ab}^{*}$ & 0.043 \\
\hline Satisfaction & $F(2.660)=24.51^{*}$ & $5.47(1.46) \mathrm{c}^{*}$ & $5.36(1.51) \mathrm{c}^{*}$ & 4.31(1.79)ab* & 0.069 \\
\hline Interest & $F(2.660)=15.59 *$ & $3.15(0.53) \mathrm{c}^{*}$ & $3.14(0.52) \mathrm{c}^{*}$ & $2.85(0.60) \mathrm{ab}^{*}$ & 0.045 \\
\hline \multicolumn{6}{|l|}{ Social Support } \\
\hline StraBL-Cognitive Strategies & $F(2.661)=11.85^{*}$ & $3.28(0.47) \mathrm{bc}^{*}$ & $\begin{array}{l}2.95(0.49) \mathrm{ac} \\
*\end{array}$ & 2.83(0.50)ab* & 0.035 \\
\hline $\begin{array}{l}\text { StraBL-Metacognitive } \\
\text { Strategies }\end{array}$ & $F(2.661)=7.91 *$ & $3.79(0.86) \mathrm{bc}^{*}$ & $2.54(0.76) \mathrm{a}^{*}$ & $3.40(0.82) \mathrm{a}^{*}$ & 0.023 \\
\hline StraBL-Internal Resources & $F(2.661)=11.84 *$ & $3.74(0.83) \mathrm{bc}^{*}$ & $\begin{array}{l}3.45(0.73) \mathrm{ac} \\
*\end{array}$ & $3.28(0.80) \mathrm{ab}^{*}$ & 0.035 \\
\hline StraBL-External Resources & $F(2.661)=8.81 *$ & $3.51(0.89) \mathrm{bc} *$ & $3.25(0.74) \mathrm{a}^{*}$ & $3.10(0.82) \mathrm{a}^{*}$ & 0.026 \\
\hline StraBL-Motor Strategies & $F(2.661)=8.76^{*}$ & $3.65(0.85) b c^{*}$ & $3.40(0.69) \mathrm{a}^{*}$ & $3.26(0.77) \mathrm{a}^{*}$ & 0.026 \\
\hline Satisfaction & $F(2.660)=1.23 *$ & $5.88(1.47) b_{c}^{*}$ & $\begin{array}{l}5.47(1.47) \mathrm{ac} \\
*\end{array}$ & $4.13(1.75) \mathrm{ab}^{*}$ & 0.146 \\
\hline Interest & $F(2.660)=1.23^{*}$ & $3.34(0.54) b c^{*}$ & $\begin{array}{l}3.10(0.53) \mathrm{ac} \\
*\end{array}$ & $2.82(0.59) \mathrm{ab}^{*}$ & 0.080 \\
\hline$* \mathrm{p}<0.05$ & MANOVA & Post-hoy & & www.macrothin & \\
\hline
\end{tabular}


SRML, satisfaction, and interest or resulted in a medium level. Accordingly, the students perceiving their teachers' behavior on a higher level than that perceived by the teachers themselves seemed to have the strongest impact on students' SRML, satisfaction, and interest.

\subsection{Teachers' perception and students' preference}

For the incongruent and congruent fit-constellations of the students' preference of their teachers' behavior and teachers' perception of their own behavior, three groups were identified: (a) students prefer more specific teaching behavior than their teachers rate themselves, (b) the students' preference of specific teaching behavior and teachers' perception of their own specific teaching behavior are consistent, and (c) students prefer less specific teaching behavior than their teachers rate themselves (see Table 5). From a general perspective the results of the last analyses were in line with the results of section three in that students scored higher on most of the scales when their rating of the preference for a specific teaching behavior was higher compared to the self-perception rate of the teachers. The congruence group scored on a medium level whereas under the condition that the teachers rated themselves higher compared to the students' preference the mean scores showed the lowest results.

Most interestingly, however, a congruent fit-constellation between students' preference and teachers' self-description seems to enhance the students' satisfaction and interest in PE on the LSS-PE dimension of Positive Feedback. For the LSS-PE dimensions Education and Instruction and Democratic Behavior, no significant group differences for satisfaction were found. Furthermore, students' interest in PE shows comparable results in the remaining LSS-PE dimensions to the StraBL scales, and in the case of Social Support, also students' satisfaction. 
Table 5

Students' SRML, Satisfaction and Interest among congruent and incongruent fit-constellations of teacher behavior preferred by students and teachers' perception of their own behavior

\begin{tabular}{|c|c|c|c|c|c|c|}
\hline \multirow{3}{*}{ Variable } & \multirow{3}{*}{$F(\mathrm{df} / \mathrm{N})$} & \multicolumn{5}{|c|}{$\begin{array}{l}\text { Comparison of } \\
\text { LSS-PE- Preference and LSS-PE-Teacher }\end{array}$} \\
\hline & & $\begin{array}{l}\text { Preference > } \\
\text { (a) }\end{array}$ & Teacher & $\begin{array}{l}\text { Congruent } \\
\text { (b) }\end{array}$ & $\begin{array}{l}\text { Preference }<\text { Teacher } \\
\text { (c) }\end{array}$ & $\eta^{2}$ \\
\hline & & $\mathrm{M}(\mathrm{SD})$ & & $\mathrm{M}(\mathrm{SD})$ & $\mathrm{M}(\mathrm{SD})$ & \\
\hline \multicolumn{7}{|l|}{ Education and Instruction } \\
\hline StraBL-Cognitive Strategies & $F(2.657)=28.21 *$ & $3.83(0.77) \mathrm{bc}^{*}$ & & $\begin{array}{l}3.57(0.74) \mathrm{ac} \\
*\end{array}$ & $3.23(0.81) \mathrm{ab}^{*}$ & 0.079 \\
\hline $\begin{array}{l}\text { StraBL-Metacognitive } \\
\text { Strategies }\end{array}$ & $F(2.657)=31.88^{*}$ & $3.94(0.79) b c^{*}$ & & $\begin{array}{l}3.71(0.75) \mathrm{ac} \\
*\end{array}$ & $3.32(0.77) \mathrm{ab}^{*}$ & 0.089 \\
\hline StraBL-Internal Resources & $F(2.657)=29.97 *$ & $3.86(0.82) \mathrm{bc}^{*}$ & & $\begin{array}{l}3.57(0.73) \mathrm{ac} \\
*\end{array}$ & $3.25(0.73) \mathrm{ab}^{*}$ & 0.084 \\
\hline StraBL-External Resources & $F(2.657)=20.97 *$ & $3.62(0.78) b c^{*}$ & & $\begin{array}{l}3.35(0.77) \mathrm{ac} \\
*\end{array}$ & $3.09(0.77) a b^{*}$ & 0.060 \\
\hline StraBL-Motor Strategies & $F(2.657)=25.16^{*}$ & $3.76(0.74) b c^{*}$ & & $\begin{array}{l}3.51(0.70) \mathrm{ac} \\
*\end{array}$ & $3.22(0.72) \mathrm{ab}^{*}$ & 0.071 \\
\hline Satisfaction & $F(2.654)=1.48$ & $4.45(2.08)$ & & $4.76(1.75)$ & $4.52(1.70)$ & 0.005 \\
\hline Interest & $F(2.654)=5.22 *$ & $3.04(0.61) \mathrm{c}^{*}$ & & $2.99(0.58) \mathrm{c}^{*}$ & $2.86(0.59) \mathrm{ab}^{*}$ & 0.016 \\
\hline \multicolumn{7}{|l|}{ Democratic Behavior } \\
\hline StraBL-Cognitive Strategies & $F(2.654)=28.12 *$ & $3.64(0.80) \mathrm{bc}^{*}$ & & $3.34(0.73) \mathrm{a}^{*}$ & $3.09(0.76) \mathrm{ab}^{*}$ & 0.080 \\
\hline $\begin{array}{l}\text { StraBL-Metacognitive } \\
\text { Strategies }\end{array}$ & $F(2.654)=31.12 *$ & $3.76(0.78) b c^{*}$ & & $3.43(0.72) \mathrm{a}^{*}$ & $3.20(0.76) \mathrm{ab}^{*}$ & 0.087 \\
\hline StraBL-Internal Resources & $F(2.654)=26.39 *$ & $3.64(0.78) b c^{*}$ & & $3.33(0.70) \mathrm{a}^{*}$ & $3.15(0.68) \mathrm{a}^{*}$ & 0.075 \\
\hline StraBL-External Resources & $F(2.654)=25.77 *$ & $3.46(0.78) \mathrm{bc}^{*}$ & & $3.11(0.73) \mathrm{a}^{*}$ & $2.97(0.76) \mathrm{a}^{*}$ & 0.073 \\
\hline StraBL-Motor Strategies & $F(2.654)=21.33^{*}$ & $3.56(0.73) b c^{*}$ & & $3.34(0.73) \mathrm{a}^{*}$ & $3.12(0.69) \mathrm{ab}^{*}$ & 0.062 \\
\hline Satisfaction & $F(2.651)=1.56$ & $4.63(1.88)$ & & $4.73(1.55)$ & $4.39(1.73)$ & 0.005 \\
\hline Interest & $F(2.651)=3.42 *$ & $2.99(0.60) \mathrm{c}^{*}$ & & $2.89(0.58)$ & $2.85(0.59) \mathrm{a}^{*}$ & 0.010 \\
\hline \multicolumn{7}{|l|}{ Positive Feedback } \\
\hline StraBL-Cognitive Strategies & $F(2.654)=14.72 *$ & $3.62(0.78) \mathrm{c}^{*}$ & & $3.62(0.83) \mathrm{c}^{*}$ & $3.28(0.78) a b^{*}$ & 0.043 \\
\hline $\begin{array}{l}\text { StraBL-Metacognitive } \\
\text { Strategies }\end{array}$ & $F(2.654)=18.38 *$ & $3.79(0.80) \mathrm{c}^{*}$ & & $3.72(0.79) \mathrm{c}^{*}$ & $3.38(0.77) \mathrm{ab}^{*}$ & 0.053 \\
\hline StraBL-Internal Resources & $F(2.654)=13.01 *$ & $3.66(0.80) \mathrm{c}^{*}$ & & $3.59(0.83) \mathrm{c}^{*}$ & $3.31(0.70) \mathrm{ab}^{*}$ & 0.038 \\
\hline StraBL-External Resources & $F(2.654)=11.68 *$ & $3.43(0.84) c^{*}$ & & $3.41(0.78) \mathrm{c}^{*}$ & $3.12(0.76) \mathrm{ab}^{*}$ & 0.035 \\
\hline StraBL-Motor Strategies & $F(2.654)=11.30^{*}$ & $3.59(0.75) \mathrm{c}^{*}$ & & $3.52(0.74) \mathrm{c}^{*}$ & $3.28(0.73) \mathrm{ab}^{*}$ & 0.034 \\
\hline Satisfaction & $F(2.651)=5.08^{*}$ & $4.09(1.89) \mathrm{bc}^{*}$ & & $4.75(1.82) \mathrm{a}^{*}$ & $4.64(1.70) \mathrm{a}^{*}$ & 0.015 \\
\hline Interest & $F(2.651)=4.13^{*}$ & $2.90(0.57)$ & & $3.03(0.60) c^{*}$ & $2.88(0.59) b^{*}$ & 0.013 \\
\hline \multicolumn{7}{|l|}{ Social Support } \\
\hline StraBL-Cognitive Strategies & $F(2.654)=21.80 *$ & $3.69(0.77) b c^{*}$ & & $\begin{array}{l}3.36(0.76) \mathrm{ac} \\
*\end{array}$ & $3.01(0.97) a b^{*}$ & 0.063 \\
\hline $\begin{array}{l}\text { StraBL-Metacognitive } \\
\text { Strategies }\end{array}$ & $F(2.654)=23.62 *$ & $3.79(0.77) b c^{*}$ & & $3.48(0.74) \mathrm{a}^{*}$ & $3.08(0.95) \mathrm{ab}^{*}$ & 0.068 \\
\hline StraBL-Internal Resources & $F(2.654)=22.88 *$ & $3.71(0.77) \mathrm{bc}^{*}$ & & $3.35(0.69) \mathrm{a}^{*}$ & $3.11(0.95) \mathrm{ab}^{*}$ & 0.066 \\
\hline StraBL-External Resources & $F(2.654)=20.64 *$ & $3.51(0.78) \mathrm{bc}^{*}$ & & $3.17(0.74) \mathrm{a}^{*}$ & $2.90(0.92) \mathrm{ab}^{*}$ & 0.060 \\
\hline StraBL-Motor Strategies & $F(2.654)=20.87 *$ & $3.63(0.73) b c^{*}$ & & $3.33(0.69) \mathrm{a}^{*}$ & $3.02(0.88) \mathrm{ab}^{*}$ & 0.060 \\
\hline Satisfaction & $F(2.652)=20.33 *$ & $4.99(1.84) b c^{*}$ & & $4.54(1.67) \mathrm{a}^{*}$ & $3.39(1.64) \mathrm{ab}^{*}$ & 0.059 \\
\hline Interest & $F(2.652)=16.21 *$ & $3.06(0.56) \mathrm{bc} *$ & & $2.91(0.58) \mathrm{a}^{*}$ & $2.59(0.68) \mathrm{ab}^{*}$ & 0.048 \\
\hline
\end{tabular}

\section{Discussion}


In the present study we examined students' use of self-regulated motor learning strategies with regard to a congruent or incongruent fit-constellation of perceived and preferred teaching behavior. Preferred and perceived teaching behavior was assessed both by the students' ratings and the teachers' self-descriptions. In addition, we focused on differential effects of teacher-student fit-constellations on students' SRML-strategies and the students' satisfaction and interest in PE.

\subsection{Fit-constellations of the three LSS-PE versions}

The group comparison of the three fit-constellation-types of students' perception and preference of teaching behavior revealed a consistent pattern of students' SRML strategy use concerning the LSS-PE dimension Education and Instruction. With regard to all StraBL scales, students seemed to apply more SRML-strategies under the condition that their perception and preference of teaching behavior were concordant and/or under the condition that they perceived less teaching behavior than preferred. By contrast, SRML-strategy use decreased when students perceived more teaching behavior than they preferred. This effect was also significant for the StraBL subscale Metacognitive Strategies in the LSS-PE dimensions of Democratic Behavior and Social Support. No significant group differences emerged for the dimension of Positive Feedback. For all LSS-PE dimensions, the mean scores of students' satisfaction and interest in PE were highest in the group with a congruent fit-constellation.

Group comparisons concerning the fit-constellations of the students' perception of teaching behavior and the teachers' self-description, and students' preference of teaching behavior and teachers' self-description, respectively, showed comparable results. For all of the StraBL subscales as well as the LSS-PE dimensions, students' use of SRML-strategies was highest when they either perceived or preferred more teaching behavior than was given by the teachers' self-descriptions. In contrast, students' use of SRML-strategies was moderate in the congruent fit-constellation and lowest when the teaching behavior scores from the teachers' self descriptions exceeded the students' perception or preference of the respective behavior (see tables 4 and 5). The comparisons of students' satisfaction and interest in PE were yet again different. With regards to the comparison of the fit-constellations of the teaching behavior perceived by the students, and the teachers' self-description, the findings were comparable to that of the StraBL subscales (see figure 1).

Figure 1

Students' Interest and Meatacognitive Strategies among the different LSS-PE constellations exemplarily for the subscale Instruction and Education 

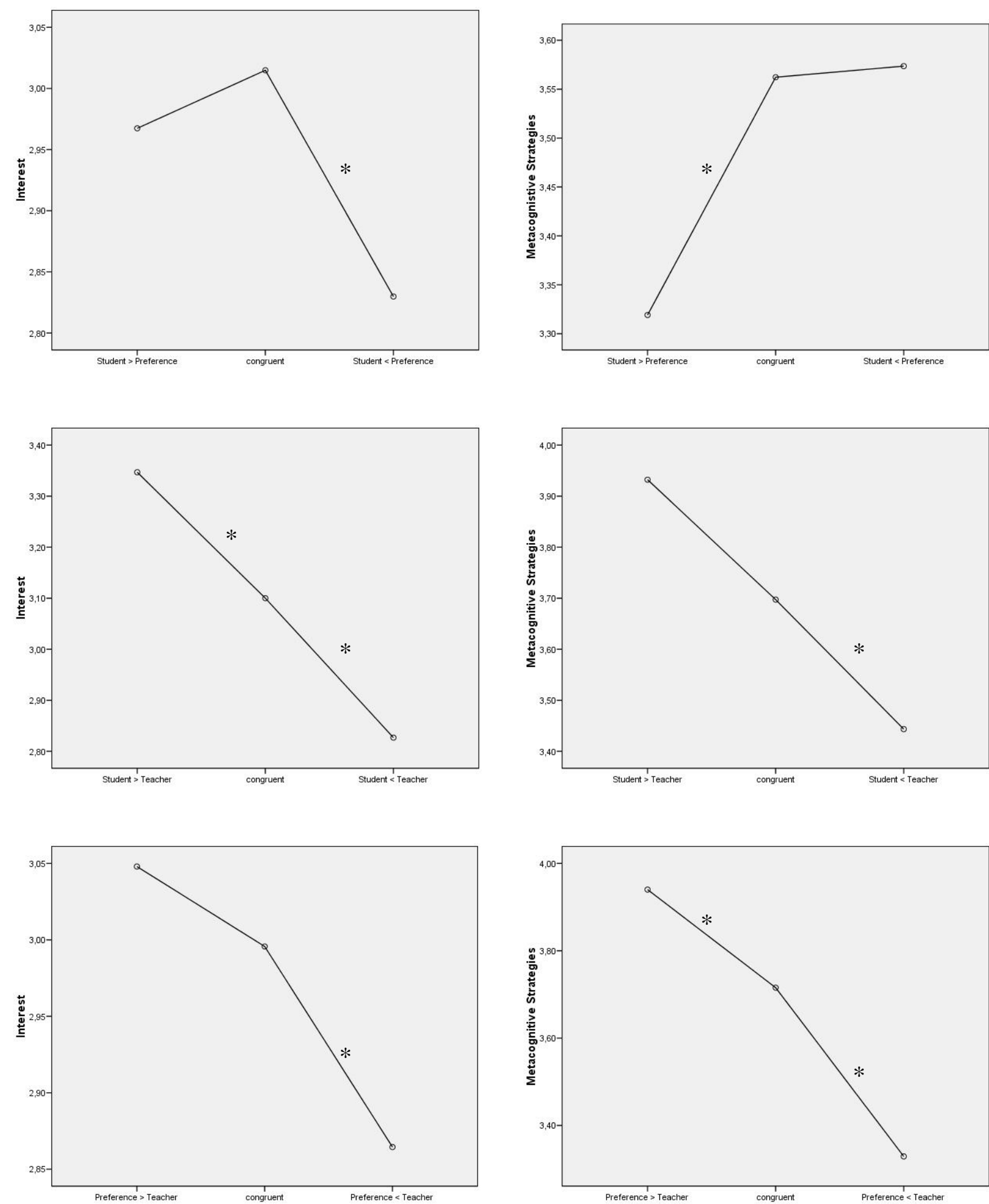

*significant difference only compared to the congruent group

The group comparisons concerned with satisfaction and interest in PE for the fit-constellation of the students' preferred teaching behavior and the teachers' self-description, however, differ from the other results. With regard to the LSS-PE dimension of Positive Feedback, a congruent fit-constellation was most beneficial for the students' satisfaction and interest in PE. In the dimensions of Education and Instruction and Democratic Behavior, the group differences for interest were comparable to the StraBL scales and group differences for satisfaction were not 
significant. Finally, rates for the dimension of Social Support for satisfaction and interest in PE revealed a group comparison similar to the pattern of the StraBL.

Our study demonstrates that three types of teacher-student fit-constellations have a different impact on students' usage of SRML-strategies. More specifically, we found that beyond a constellation of congruency, other constellations seem to bear a crucial effect on strategic behavior, too. When students perceive less specific teaching behavior than the one they were actually claiming for, they seem to apply at least a similar amount of SRML-strategies than in the congruent condition. However, when students perceive more specific teaching behavior than they prefer, their SRML-strategy use decreases. In our study, the LSS-PE dimension Education and Training showed this effect for all StraBL scales. In addition, this effect was also relevant for the StraBL-subscale of Metacognitive Strategies in the dimensions Democratic Behavior and Social Support. Hence, it seems to be of importance that the students' perception and preference of teaching behavior are congruent. This result is in line with findings regarding the congruence hypothesis of the multidimensional leadership model (Chelladurai, 1978; Chelladurai, 1984; Horne \& Carron, 1985; Riemer \& Chelladurai, 1995; Lindberg et al., submitted). So far, findings on the congruence hypothesis have referred only to satisfaction and other outcome variables (e.g. performance and achievement). The assumption that the congruence hypothesis might also be related to self-regulated learning strategies, however, seems to be novel.

\subsection{Compensation/decompensation effect}

A possible explanation for the different impacts of the three types of teacher-student fit-constellation on the students' usage of SRML-strategies might be due to the students' need to regulate their own learning behavior adaptively according to the teaching context. On the one hand, they have to compensate their strategy use with endeavors of their own in a situation where the instructions they need are missing. On the other hand, they decompensate with a considerable strategy decrease when too many external instructions are given. Since the LSS-PE-Student and LSS-PE-Preference assessments measure the students' subjective perception of what is given and what should be given, it seems reasonable to interpret the aforementioned results in terms of students' activities in self regulating their teaching circumstances. Effects of decompensation can emerge when the instruction or feedback of the teacher is too specific and therefore interferes with the learning process of the students (Magill \& Wood, 1986). Moreover, it is possible that due to this interference, students reduce their own endeavors in SRML to meet the teacher's demands (Kuhl, 2000). In this regard Ryan and Deci (2000) noted that students complying with the assumed demands of a teacher are less intrinsically motivated and a voluntary investment in self-regulated learning becomes rather unlikely. When students are more self-controlled and not under the influence of strong external instructions and feedback, however, this can lead to more effective learning (Wulf \& Toole, 1999) to higher motivation, increased self-efficacy, and enriched goal-setting (Deci \& Ryan, 2000). This observation is in line with findings of SDT stating that autonomy-supportive teaching led to greater learning and performance than strict controlling teaching (Vansteenkiste, Simons, Soenens, \& Lens, 2004). Presumably, self-regulated students who monitor their own learning and goal-setting behavior and generate internal feedback loops during that process can also interpret and use external feedback more adequately (Butler \& Winne, 1995). Correspondingly, Chiviacowsky and Wulf (2002) reported that self-regulated students request external feedback based on the self-estimation of their own performance. Furthermore, Sadler (1989) stated that students are able to compare their own performance with a current standard and they try to fill the gaps. 
The examination of the three fit-constellation types of students' perception of teaching behavior and teachers' self-description revealed that students were less satisfied, less interested in PE, and applied less SRML-strategies when their teacher perceived his or her own behavior to rate higher than they did. A similar pattern of results was observable regarding the comparison of the fit-constellation of the students' preference of teaching behavior and teachers' self-description. For the interpretation of these results, we take into consideration the aforementioned compensation/decompensation phenomenon. We defined the compensation effect to occur on the one hand in situations during which students perceive a gap between what is given and what should be given and therefore develop stronger attitudes and self-regulated behavior. We expect the decompensation effect, however, to occur in situations where students perceive an overregulation by their teachers and seem thus to be affected in their attitudes and self-regulated behavior. The examination of the fit-constellations revealed that when teachers perceived themselves as more salient in their way of teaching than their students perceived or preferred their teaching behavior, students felt overregulated. As a consequence, the students were less satisfied and less interested and they used fewer self-regulated learning strategies.

\subsection{Limitations and future directions}

In literature, the self-assessment behavior of teachers has often been criticized (Boekaerts, 1991; Nwosu, 1995), and the teachers' implicit beliefs about teaching efficacy have assumedly affected their self-assessment (Bandura, 1982; Pape, 1992). Research in organizational psychology has also revealed that self-ratings are poor predictors of performance (Church, 2000; Sala \& Dwight, 2002) and that self-assessment is often biased by a lenience towards oneself (Church, 1997; Van Velsor, Taylor, \& Leslie, 1993). Behavioral ratings by others (i.e. students in our context) are presumably more adequate. These ratings can be used as an external feedback, which can lead to an improved self-awareness and a change in individual development (Church, 2000; Sala \& Dwight, 2002). Hence, the claim is met that the students' perceptions of their teachers' behavior should be considered as a crucial mediator between instructional characteristics and academic achievement (Walberg, 1976; Winne \& Marx, 1997). If teachers use external feedback for a self-controlled modification of their teaching behavior, they can better meet the needs of their students (Hatton \& Smith, 1995).

In the present study we have only subjective information based on students' and teachers self-report. In addition, we used questionnaires at only at one measurement point. Thus, we cannot discuss causation effects. Moreover, findings from this study can only be generalized with caution owing to the limited numbers of students and teachers in particular. The procedure we used can be seen as a first approach to gaining interesting insights into students' self-regulating learning in PE under the influence of their teachers. Further research may focus on larger samples, alternative approaches, such as classroom observation, interviews, and the assessment of actual behavior and on longitudinal measurement. Such advancements are necessary to support and improve the findings of this work.

\subsection{Conclusion}

In summary, the results of our study indicate that congruent and incongruent fit-constellations among students and teachers differ with regard to their impact on the students' self-regulated motor learning. It is not only important that teachers and students agree in their perception, it is moreover indispensable that a teacher is aware that too much instruction may overregulate his or her students and may in turn lead to a lack of independent and self-regulated learning. The LSS instrument used in this study may be useful as a tool for teachers to assess whether their teaching behavior is seen as overregulating or not. When teachers ask for the subjective opinions of their students of what is given and what should be given, they can hopefully teach more individually and adaptively. 


\section{Acknowledgements}

We would like to thank all the participating students and teachers. Moreover, we are grateful to our student assistants for their help with data collection and analysis.

\section{References}

Almond, L., \& Harris, J., (1998). Interventions to promote health-related physical education. In S. Biddle, J. Sallis, \& N. Cavill (Eds.), Young and active? Young people and health enhancing physical activity: Evidence and implications (pp. 133-149). London: Health Education.

Anderssen, N. (1993). Perception of physical education classes among young adolescents: Do physical education classes provide equal opportunities to all students? Health Education Research, 8, 167-179. http://dx.doi.org/10.1093/her/8.2.167

Arnold, P. (1991). The Pre-eminence of skill as an educational value in the movement curriculum, Quest, 43, 66-77. http://dx.doi.org/10.1080/00336297.1991.10484011

Artelt, C., Baumert, J., Klieme, E., Neubrand, M., Prenzel, M., Schiefele, U., Schneider, W., Tillmann, K. J., \& Weiß, M. (2000). Self-Regulated Learning as a Cross-Curricular Competence. Paris: Organisation for Economic Co-operation and Development.

Bandura, A. (1982). Self-efficacy mechanism in human agency. American Psychologist, 37, 122-147. http://dx.doi.org/10.1037/0003-066X.37.2.122

Bergen, T., Van Amelsfoort, J., \& Setz, W. (1994) Het lesgedrag van docenten in relatie tot de vakspecifieke motivatie van leerlingen [Classroom behaviour of teachers in relation to the specific subject motivation of students], Pedagogische Studien, 71, 256-270.

Boekaert, M. (1991). Subjective Competence Appraisals and Self Assessment of Learning and Instruction. Journal of European Association for Research on Leaning and Instruction, 10. 3 - 12.

Boekaerts, M. (1999a). Self-regulated learning: Where we are today. International Journal of Educational Research, 31, 445-475. http://dx.doi.org/10.1016/S0883-0355(99)00014-2

Boekaerts, M. (1999b). Coping in context, goal frustration and goal ambivalence in relation to academic and interpersonal goals. In E. Frydenberg (Ed.) Learning to cope: developing as a person in complex societies (175-197). Oxford: Oxford University Press.

Brekelmans, J.M.G., Wubbels, T., \& Creton, H.A. (1989). Een typologie van leerlingenpercepties van leraargedrag [A typology of student perceptions of teacher behaviour], Pedagogische Studien, 66, 315 - 326.

Bund, A., \& Wiemeyer, J. (2005). Strategien beim selbstgesteuerten Bewegungslernen:

Ergebnisse zur Validität und Reliabilität eines neuen Fragebogens. Zeitschrift für Sportpsychologie, 12, 22-34. http://dx.doi.org/10.1026/1612-5010.12.1.22

Butler, D.L., \& Winne, P.H. (1995) Feedback and self-regulated learning: a theoretical synthesis, Review of Educational Research, 65, 245-281. http://dx.doi.org/10.3102/00346543065003245

Carlson. T.B. (1995). We hate gym: Student alienation from physical education. Journal for Teaching in Physical Education, 14, 467-477.

Chelladurai, P. (1978). A contingency model of leadership in athletics. Unpublished doctoral dissertation. University of Waterloo, Canada.

Chelladurai, P. (1984). Discrepancy between preferences and perceptions of leadership behaviour and satisfaction of athletes in varying sports. Journal of Sport Psychology, 6, 27-41.

Chelladurai, P., \& Saleh, S.D. (1980). Dimensions of leader behavior in sports: Development of a leadership scale. Journal of Sport Psychology, 2, 34-45. 
Chirkov, V. I., \& Ryan, R. M. (2001). Parent and teacher autonomy-support in Russian and

U.S. adolescents: Common effects on well-being and academic motivation. Journal of $\begin{array}{llllll}\text { Cross Cultural } & \text { Psychology, } & 32, & 618 & - & 635 .\end{array}$ http://dx.doi.org/10.1177/0022022101032005006

Chiviakowsky, S., \& Wulf, G. (2002). Self-controlled feedback: Does it enhance learning because performers get feedback when they need it? Research Quarterly for Exercise and Sport, 73, 408-415. http://dx.doi.org/10.1080/02701367.2002.10609040

Choi, J.I., \& Hannafin, M. (1995) Situated cognition and learning environments: roles, Structures, and implications for design. Educational Technology Research and Development, 43, 53 - 69. http://dx.doi.org/10.1007/BF02300472

Church, A. H. (1997). Managerial self-awareness in high-performing individuals in organizations. Journal of Applied Psychology, 82, 281-292. http://dx.doi.org/10.1037/0021-9010.82.2.281

Church, A. H. (2000). Do higher performing managers actually receive better ratings? A validation of multi-rater assessment methodology. Consulting Psychology Journal: Practice and Research, 54, 166-172.

Corno, L. (2001). Volitional aspects of self-regulated learning. In B.J. Zimmerman \& D.H. Schunk (Eds.), Self-regulated learning and academic achievement: Theoretical perspectives (2nd edn., pp. 191-226). Mahwah, NJ: Lawrence Erlbaum.

Davidson, J.E., \& Stenberg, J.R. (1985). Competence and performance: Intellectual development. In E. Neimark (Ed.), Moderators of competence (pp. 43-76). Hillsdale, NJ: Laurence Erlbaum.

Deci, E. L., Schwartz, A. J., Sheinman, L., \& Ryan, R. M. (1981). An instrument to assess adults' orientations toward control versus autonomy with children: Reflections on intrinsic motivation and perceived competence. Journal of Educational Psychology, 73, 642-650. http://dx.doi.org/10.1037/0022-0663.73.5.642

Deci, E. L., Koestner, R., \& Ryan, R. M. (1999). A meta-analytic review of experiments examining the effects of extrinsic rewards on intrinsic motivation. Psychological Bulletin, 125, 627-668. http://dx.doi.org/10.1037/0033-2909.125.6.627

Deci, E., \& Ryan, R. (2000). What is the self in self-directed learning? Findings from recent motivational research. In G.A. Straka (Ed.), Conceptions of self-directed learning (75-92). New York: Waxmann.

DeGrave, W., Boshuizen, H.P.A., \& Schmidt, H.G. (1999) Probleemgestuurd leren als kennisconstructie [Problem-directed learning as knowledge construction], Onderzoek van Onderwijs, 6, $22-24$.

Dishman.R.K., Sallis, J.F., \& Orenstein.D.R. (1985) The determinants of physical activity and exercise. Public Health Reports, 100, 158-171

Elbe, A.-M., Szymanski, B., \& Beckmann, J. (2005) The development of volition in young athletes. Psychology of Sport and Exercise, 6, 559-569. http://dx.doi.org/10.1016/j.psychsport.2004.07.004

Feltz, D.L., \& Langer, D.M. (1983). The effects of mental practice on motor skill learning and performance: A meta-analysis. Journal of Sport Psychology, 5, 25-27.

Ferguson,K.J., Yesalis.C.E., Pomrehn,P.R., \& Kirkpatrick,M.B. (1989) Attitudes, knowledge, and beliefs as predictors of exercise intent and behavior in school children. Journal of School Health, 59, 112-115. http://dx.doi.org/10.1111/j.1746-1561.1989.tb04675.x

Fraser, B.J. (1998). Science learning environments: assessment, effects and determinants. In B.J. Fraser \& K.G. Tobin (Eds.), The international handbook of science education (pp.527-564). Dordrecht: Kluwer. http://dx.doi.org/10.1007/978-94-011-4940-2_31 
Gallagher, J.D., \& Thomas, J.R. (1984). Rehearsal strategy effects on developmental differences for recall of a movement series. Research Quarterly for Exercise and Sport, 55, 123-128. http://dx.doi.org/10.1080/02701367.1984.10608387

Gallagher, J.D., \& Thomas, J.R. (1986). Developmental effects of grouping and recoding on learning a movement series. Research Quarterly for Exercise and Sport, 57, 117-127.

Glencross, D.J. (1994). Human skill and motor learning: A critical review. Sport Science Review, 1, 65-78.

Goudas, M., Dermitzaki, I., \& Bagiatis, K. (2001). Motivation in physical education is correlated with participation in sport after school. Psychological Reports, 88, 491-496. http://dx.doi.org/10.2466/pr0.2001.88.2.491

Graham G., Holt-Hale. S.A., \& Parker. M. (1998). Children moving: A reflective approach to teaching physical education (4th ed.). Mountain View, CA: Mayfield.

Grolnick, W. S., Ryan, R. M., \& Deci, E. L. (1991). The inner resources for school achievement: Motivational mediators of children's perceptions of their parents. Journal of Educational Psychology, 83, 508 -517. http://dx.doi.org/10.1037/0022-0663.83.4.508

Hagger, M. S., Chatzisarantis, N. L., Culverhouse, T., \& Biddle, S. J. (2003). The processes by which perceived autonomy support in physical education promotes leisure-time physical activity intentions and behavior: A trans-contextual model. Journal of Educational Psychology, 95, 784-795. http://dx.doi.org/10.1037/0022-0663.95.4.784

Hatton, N., \& Smith, D. (1995). Reflection in teacher education: Towards definition and implementation. Teaching and Teacher Education, 11, 33-49. http://dx.doi.org/10.1016/0742-051X(94)00012-U

Horne, T., \& Carron, A.V. (1985). Compatibility in coach-athlete relationships. Journal of Sport Psychology, 7, 137-149.

Köller, O. (2004). Konsequenzen schulischer Leistungsgruppierung. Münster: Waxmann.

Kuhl, J. (2000). A functional design approach to motivation and self-regulation: The dynamics of personality systems and interactions. In M. Boekaerts, P. Pintrich, \& M. Zeidner (Eds.), Handbook of self-regulation (pp. 111-163). San Diego, California: Academic. http://dx.doi.org/10.1016/B978-012109890-2/50034-2

Lavisse, D., Deviterne, D., \& Perrin, P. (2000). Mental processing in motor skill acquisition by young subjects. International Journal of Sport Psychology, 31, 364-375.

Levy, J.,Wubbels, T., \& Brekelmans, M. (1992) Student and teacher characteristics and perceptions of teacher communication style, Journal of Classroom Interaction, 27, 23 29.

Lidor, R. (2004). Developing meta-cognitive behaviour in physical education classes: The use of task-pertinent learning strategies. Physical Education and Sport Pedagogy, 9, 55-71. http://dx.doi.org/10.1080/1740898042000124

Lindberg, S., Hasselhorn, M., \& Lehmann, M. (unpublished manuscript). The impact of perceived teacher-student congruence in physical education on students' satisfaction.

Magill, R. A., \& Wood, C. A. (1986). Knowledge of results as a learned variable in motor skill acquisition. Research Quarterly for Exercise and Sport, 57, 170-173.

Ntoumanis, N. (2005). A prospective study of participation in optional school physical education using a self-determination theory framework. Journal of Educational Psychology, 97, 444-453. http://dx.doi.org/10.1037/0022-0663.97.3.444

Nunnally, J. C. (1978). Psychometric theory. (2nd ed.). New York: McGraw-Hill.

Nwosu, E.C. (1995). Development, validation and application of a model for assessing teacher effectiveness in secondary school hemistry. Unpublished Ph.D. Thesis, University of Lagos.

O'Sullivan, M. (2004). Possibilities and pitfalls of a public health agenda for physical 
education. Journal of Teaching in Physical Education, 23, 392-404.

Pape. S. L. (1992). Personal theorizing of an intern teacher. In J.W.C.E.W. Ross \& G.

McCutcheon (Ed.), Teacher personal theorizing (pp. 67-82). Albany: State University of New York Press,.

Perry, N.E. (2002). Using qualitative methods to enrich understandings of self-regulated learning. Educational Psychologist, 37, 1-3.

Perry.C, Stone.E.J., Parcel.G.S., Ellison.R.C, Nader.P.R., Webber.L.S., \& Luepker.R.V. (1990) School-based cardiovascular health promotion: The Child and Adolescent Trial for Cardiovascular Health (CATCH). Journal of School Health, 60, 406-413 http://dx.doi.org/10.1111/j.1746-1561.1990.tb05960.x

Pintrich, P.R., Smith, D.A.F., Garcia, T., \& McKeachie, W.J. (1993). Reliability and predictive validity of the Motivated Strategies for Learning Questionnaire (MSLQ). Educational and Psychological Measurement, 53, 801-813. http://dx.doi.org/10.1177/0013164493053003024

Pohlmann, B., Möller, J. \& Streblow, L. (2005). Bedingungen leistungsbezogenen Verhaltens im Sportunterricht. Zeitschrift für Sportpsychologie, 12, 127-134. http://dx.doi.org/10.1026/1612-5010.12.4.127

Randi, J., \& Corno, L. (1997). Teachers as innovators. In B.J. Biddle, T.L. Good, \& I.F. Goodson (Eds.), International handbook of teachers and teaching, Vol. I. (pp. 1163-1221). Dordrecht, The Netherlands: Kluwer Academic.

Riemer, H. A., \& Chelladurai, P. (1995). Leadership and satisfaction in athletics. Journal of Sport and Exercise Psychology, 17, 276-293.

Robinson, J.P., Shaver, P.R., \& Wrightsman, L.S (1991) Criteria for Scale Selection and

Evaluation In Measure of Personality and Social Psychological Attitudes. Calif: Academic Press, San Diego

Ryan, R. M., Connell, J.P., \& Deci, E.L. (1985). A motivational analysis of selfdetermination and self-regulation in education. In C. Ames, \& R. E. Ames (Eds.), Research on motivation in education: The classroom milieu (pp. 13-51). New York: Academic Press.

Ryan, R. M., \& Deci, E. L. (2000). An overview of self-determination theory: An organisticdialectical perspective. In E. L. Deci \& R. M. Ryan (Eds.), Handbook of self-determination research (pp. 3-34). Rochester, New York: University of Rochester.

Sadler, D. R. (1989) Formative assessment and the design of instructional systems, Instructional Science, 18, 119-144. http://dx.doi.org/10.1007/BF00117714

Sala, F., \& Dwight, S.A. (2002). Predicting executive performance with multi-rater surveys: Whom you ask makes a difference. Consulting Psychology Journal: Practice and Research, 54, 166-172. http://dx.doi.org/10.1037/1061-4087.54.3.166

Sallis, J.F. (1987). A commentary on children and fitness: A public health perspective. Research Quarterly For Exercise and Sport, 58, 326-330. http://dx.doi.org/10.1080/02701367.1987.10608108

Schunk, D.H. (1996). Goal and self-evaluative influences during children's cognitive skill learning. American Educational Research Journal, 33, 359-382. http://dx.doi.org/10.3102/00028312033002359

Schunk, D.H., \& Zimmerman, B.J. (1994). Self-regulation of learning and performance: Issues and educational applications. Hillsdale, NJ: Erlbaum.

Schunck, D.H., \& Zimmerman, B.J. (1996). Modeling and self-efficacy influences on children's development of self-regulation. In J. Juvonen \& K.R. Wentzel (Eds.), Social motivation: Understanding children's school adjustment (pp. 154-180). New York: Cambridge University Press. http://dx.doi.org/10.1017/CBO9780511571190.009 
Singer, R.N., DeFrancesco, C., \& Randall, L.E. (1989). Effectiveness of a global learning strategy practiced in different contexts on primary and transfer self-paced motor tasks. Journal of Sport \& Exercise Psychology, 11, 290-303.

SPSS for Windows, Rel. 15.0.1. 2006. Chicago: SPSS Inc.

Vansteenkiste, M., Simons, J., Soenens, B., \& Lens, W. (2004). How to become a persevering exerciser? Providing a clear, future intrinsic goal in an autonomy supportive way. Journal of Sport \& Exercise Psychology, 26, 232-249.

Van Velsor, E., Taylor, S., \& Leslie, J. B. (1993). An examination of the relationships among self-perception accuracy, selfawareness, gender, and leader effectiveness. Human Resource Management, 32, 249-263.

Van Velzen, J. (2003) Instruction and self-regulated learning: promoting student selfreflection. Unpublished dissertation, University of Leiden.

Van Wersch, A., Trew, K., \& Turner, I. (1992). Post-primary school pupils' interest in physical education: Age and gender differences. British Journal of Educational Psychology, 62, 56-72.

Vermunt, J. (1998) The regulation of constructive learning processes, British Journal of Educational Psychology, 68, 149 - 171.

Walberg, H.J. (1976) The psychology of learning environments: Behavioural, structural or perceptual? Review of Research in Education, 4, 142-178.

Weinert, F. E. (1994). Lernen lernen und das eigene lernen verstehen. In K. Reusser \& M. Reusser-Weyeneth (Hrsg.), Verstehen. Psychologischer Prozeß und didaktische Aufgabe (S. 183-205). Bern: Huber.

Weir, T. (2000, May 2). The new PE. USA Today, p. C1.

Winne, P.H., \& Marx, R.W. (1997). Reconceptualizing research on teaching, Journal of Educational Psychology, 69, 668-678.

Winter, K.T., \& Thomas, J.R. (1981). Developmental differences in children's labeling of movement. Journal of Motor Behavior, 13, 77-90.

Wulf, G., \& Toole, T. (1999). Physical assistance devices in complex motor skill learning: Benefits of a self-controlled practice schedule. Research Quarterly forExercise and Sport, 70, 265-272.

Würth, S., Saborowski, C. \& Alfermann, D. (1999). Trainingsklima und Führungsverhalten aus der Sicht jugendlicher Athleten und deren Trainer. Psychologie und Sport, 6, 146-157.

Zimmerman, B.J. (1990). Self-regulated learning and academic performance: An overview. Educational Psychologist, 25, 3-17.

Zimmerman, B.J., \& Martinez-Pons, M. (1990). Student differences in self- regulated learning: Relating grade, sex, and giftedness to self-efficacy and strategy use. Journal of Educational Psychology, 82, 51-59. 